\title{
Kedudukan Kelembagaan dan Praktik Pengelolaan Arsip di Lingkungan Perguruan Tinggi: \\ Studi pada Universitas Gadjah Mada, Universitas Negeri Yogyakarta, dan Universitas Pembangunan Nasional Veteran Yogyakarta
}

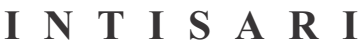

Tujuan penelitian ini adalah untuk menganalisis pelaksanaan records management dan archives administration di Universitas Gadjah Mada (UGM), Universitas Negeri Yogyakarta (UNY), dan Universitas Pembangunan Nasional Veteran Yogyakarta (UPN VY). Penelitian dilakukan dengan mengkomparasikan hasil kegiatan pengelolaan arsip dari tahun 2016-2018. Melalui pendekatan kualitatif dengan model studi komparasi, penelitian ini bermaksud menggali informasi mengenai praktik kelembagaan arsip perguruan tinggi di UGM, UNY, dan UPN VY. Hasil penelitian menunjukkan bahwa sebagai lembaga kearsipan, UGM lebih banyak dalam menyelenggarakan archives administration jika dibandingkan dengan UNY dan UPN VY. Sementara itu, pelaksanaan records management di UNY dan UPN VY jauh lebih tinggi daripada di UGM.

\section{$\begin{array}{llllllll}A & B & S & T & R & A & C & T\end{array}$}

The purpose of this study was to analyze the implementation of records management and archives administration at Universitas Gadjah Mada (UGM), Universitas Negeri Yogyakarta (UNY), and Universitas Pembangunan Nasional Veteran Yogyakarta (UPN $V Y)$. The study was conducted by comparing the results of records management activities from 2016-2018. Through a qualitative approach with a comparative study model, this study intends to explore information about the institutional practices of tertiary institutions at UGM, UNY, and UPN VY. The results of the study show that as an archival institution, UGM has more administration archives when compared to UNY and UPN VY. Meanwhile, the implementation of records management at UNY and UPN VY was much higher than at UGM.
P E N U L I S

Herman Setyawan Ratminto

Ida Fajar Priyanto

Program Studi

Magister Manajemen

Pendidikan Tinggi UGM herman.setyawan@ugm.ac.id

KATA KU N C I

Kelembagaan Arsip

Perguruan Tinggi,

Records Management, Archives Administration

KEYWORDS

Archives Administration, Institution of University Archives, Records Management 


\section{PENGANTAR}

\section{Latar Belakang Masalah}

Perguruan tinggi merupakan sebuah lembaga formal yang berkewajiban melaksanakan tridharma, yaitu tiga fungsi perguruan tinggi yang terdiri atas: pendidikan, penelitian, dan pengabdian kepada masyarakat. Perguruan tinggi menghasilkan catatancatatan informasi dalam setiap pelaksanaan kegiatan tridharma tersebut. Pelaksanaan pendidikan membutuhkan dan menghasilkan catatan resmi berupa kurikulum, silabus, nilai akademik, ijazah, dan sebagainya. Sementara itu, pelaksanaan penelitian menghasilkan karya-karya ilmiah mahasiswa, dosen, dan tenaga kependidikan yang merupakan kekayaan intelektual yang terekam dalam berbagai media dan menjadi warisan perguruan tinggi. Demikian pula pelaksanaan pengabdian kepada masyarakat, kegiatan ini menghasilkan berbagai dokumen seiring aktivitas administrasinya. Catatan-catatan tersebut merupakan dokumen akademik yang dapat diwariskan kepada sivitas akademika lintas generasi.

Stern (2007) mengatakan bahwa warisan universitas (university heritage) dirintis pertama kali di Florida State University pada 1947 oleh Mary Lou Norwood. Tiga unsur dari university heritage adalah: perpustakaan, arsip universitas/perguruan tinggi, dan museum. Perpustakaan berfokus pada koleksi pustaka, sedangkan museum berfokus pada benda-benda bersejarah. Sementara itu, arsip perguruan tinggi berfokus pada ketersediaan dan layanan informasi dalam bentuk dokumen. Sementara itu, Kirchhoff, dkk (2008:252) menyatakan bahwa arsip, perpustakaan, dan museum merupakan institusi memori: mereka mengatur catatan budaya dan intelektual. Koleksi mereka mengandung memori masyarakat, komunitas, lembaga dan individu, warisan ilmiah dan budaya, dan produk imajinasi sepanjang waktu, kerajinan dan belajar. Mereka tergabung untuk mewariskan memori kepada generasi mendatang.

Sebagai salah satu sumber warisan universitas, arsip memiliki peranan penting dalam menyediakan informasi. Memori, seperti sejarah, berakar pada arsip. Schwartz dan Cook (1992:19) mengatakan bahwa tanpa arsip, memori akan terputus-putus, pengetahuan tentang prestasi dan kebanggaan masa lalu akan memudar. Arsip menjadi solusi bagi masalah ini. Arsip berisi bukti tentang apa yang terjadi di masa lalu yang tidak mungkin lagi diceritakan secara lisan dan turun temurun. Sementara itu Trace (2002:137) mengatakan bahwa dalam pandangan tradisional, arsip tercipta sebagai produk sampingan, bukan sebagai peninggalan bagi generasi berikutnya. Namun dalam pandangan post-positivis, arsip merupakan konstruksi sosial dan dikelola oleh sebuah entitas.

Berkembangnya archival study di dunia membuka wacana yang lebih luas 
tentang pemaknaan arsip. Archival study (kajian kearsipan) adalah keseluruhan pengetahuan pada dan mengidentifikasi arsiparis profesional, termasuk teori, praktek, dan kepanditan (scholarship) sebagaimana dinyatakan dalam kurikulum keilmuan kearsipan (SulistyoBasuki, 2005:21). Selain sebagai dokumen, arsip dapat dimaknai secara lebih luas. Schwartz dan Cook (1992:13) berpendapat bahwa arsip dapat dimaknai sebagai dokumen, institusi, maupun profesi. Cook (2013:950) menambahkan bahwa terjadi empat kali pergeseran paradigma kearsipan, yaitu arsip sebagai bukti, arsip sebagai memori, arsip sebagai identitas, dan arsip sebagai komunitas.

Pemaknaan arsip sebagai dokumen, institusi, dan profesi turut berkembang di Indonesia. Arsip sebagai dokumen mulai mendapat perhatian. Lembaga kearsipan dan profesi kearsipan juga telah diakui oleh pemerintah melalui peraturan perundang-undangan. UndangUndang nomor 43 tahun 2009 tentang Kearsipan menyebutkan bahwa lembaga kearsipan adalah lembaga yang memiliki fungsi, tugas, dan tanggung jawab di bidang pengelolaan arsip statis dan pembinaan kearsipan. Lembaga kearsipan tidak saja berkembang pada ranah pemerintahan, namun juga di perguruan tinggi. Lembaga Kearsipan Perguruan Tinggi (LKPT) disebut juga sebagai Arsip Perguruan Tinggi atau Arsip Universitas.

Sebagai institusi formal, perguruan tinggi memiliki karakteristik yang berbeda dengan lembaga negara dalam penyelenggaraan kearsipan. Cohen dan March (1986:207-208) berpendapat bahwa institusi pendidikan tinggi bersifat unik. Dinamika organisasi, basis kekuatan, struktur hirarkis, dan praktik pengambilan keputusan di perguruan tinggi berbeda dari jenis organisasi lainnya. Universitas mencirikan kelemahan administrasi berbasis informasi. Informasi tentang kejadian masa lalu atau keputusan masa lalu seringkali tidak dipertahankan. Bila dipertahankan, seringkali sulit ditemukan kembali. Oleh karena itu, berkembanglah wacana mengenai kelembagaan arsip di perguruan tinggi.

Melihat perkembangan kebutuhan lembaga kearsipan, pemerintah mengeluarkan Undang-Undang Nomor 43 tahun 2009 tentang Kearsipan. Dalam undang-undang tersebut, lembaga kearsipan terdiri atas Arsip Nasional Republik Indonesia (ANRI), Arsip Daerah Provinsi, Arsip Daerah Kabupaten/Kota, dan Arsip Perguruan Tinggi. Undang-Undang Nomor 43 tahun 2009 tentang Kearsipan menyebutkan bahwa arsip perguruan tinggi adalah Lembaga Kearsipan Perguruan Tinggi yang dibentuk sesuai dengan peraturan perundang-undangan.

Kajian kearsipan di Indonesia, baik pada lembaga kearsipan pemerintah maupun Lembaga Kearsipan Perguruan Tinggi, meliputi manajemen arsip dinamis (records management) dan 
administrasi arsip statis (archives administration). Undang-Undang nomor 43 tahun 2009 tentang Kearsipan menyebutkan bahwa arsip dinamis adalah arsip yang digunakan secara langsung dalam kegiatan pencipta arsip dan disimpan selama jangka waktu tertentu. Sementara itu arsip statis adalah arsip yang dihasilkan oleh pencipta arsip karena memiliki nilai guna kesejarahan, telah habis retensinya, dan berketerangan dipermanenkan yang telah diverifikasi baik secara langsung maupun tidak langsung oleh Arsip Nasional Republik Indonesia dan/atau lembaga kearsipan. Manajemen arsip dinamis dan administrasi arsip statis merupakan sebuah rangkaian pengelolaan arsip berdasarkan fungsinya.

Manajemen arsip dinamis (records management) diadopsi dari konsep Life Cycle of Records. Konsep ini dicetuskan oleh Theodore Roosevelt Schellenberg dari Arsip Nasional Amerika Serikat pada 1934 (Shephred \& Yeo, 2003: 5). Ricks \& Gow (1988:4) mengatakan bahwa konsep Life Cycle of Records ini membagi daur hidup arsip menjadi tiga tahap, yaitu:

1. Penciptaan atau penerimaan (tahap lahir arsip)

2. Penggunaan dan pemeliharaan arsip dinamis (tahap hidup produktif)

3. Tahap penyusutan arsip dinamis (tahap kematian) atau pemindahan ke tempat arsip statis (reinkarnasi).

Administrasi arsip statis (archives administration) merupakan tahap hidup kedua bagi suatu dokumen. Kennedy dan Schauder (1998:9) mengatakan bahwa akhir dari daur hidup arsip dinamis akan memasuki tahap/siklus hidup ke dua sebagai arsip yang diidentifikasi dan dinilai sebagai arsip yang memiliki nilai guna keberlanjutan, dikumpulkan, dicatat informasinya, dipelihara, serta diberikan atau disediakan akses arsipnya. Pearce-Moses (2005:91) mengatakan bahwa nilai keberlanjutan (continuing value) adalah kegunaan atau signifikasi jangka panjang suatu arsip yang didasarkan pada nilai guna administrasi, hukum, fiskal, kebuktian, atau historis yang terkandung di dalamnya dan perlu dilestarikan secara terusmenerus.

Undang-Undang nomor 43 tahun 2009 tentang Kearsipan menyatakan bahwa pengelolaan arsip dinamis meliputi: 1) penciptaan, 2) penggunaan dan pemeliharaan, dan 3) penyusutan. Dalam konsep kearsipan, ketiga tahapan tersebut dapat disebut records management dan merupakan tugas dan tanggung jawab unit pengolah dan unit kearsipan. Sementara itu, pengelolaan arsip statis meliputi: 1) akuisisi, 2) pengolahan, 3) preservasi, dan 4) akses. Tahapan tersebut merupakan tugas dan tanggung jawab lembaga kearsipan.

Sedikit berbeda dengan undangundang, menurut Peraturan Menteri Riset, Teknologi, dan Pendidikan Tinggi Nomor 78 tahun 2017 tentang Penyelenggaraan 
Kearsipan di Lingkungan Kementerian Riset, Teknologi, dan Pendidikan Tinggi disebutkan bahwa pengelolaan arsip dinamis terdiri atas: 1) penciptaan arsip, 2) penggunaan arsip, 3) pemeliharaan arsip, dan 4) penyusutan arsip. Peraturan tersebut juga menyatakan bahwa dalam ranah perguruan tinggi, unit pengolah berada pada masing-masing unit kerja, dan unit kearsipan II berada di tingkat fakultas, biro, pascasarjana, dan lembaga (selain lembaga kearsipan), dan unit pelaksana teknis, sedangkan unit kearsipan I berada pada biro universitas. Lembaga Kearsipan Perguruan Tinggi (LKPT) berfungsi sebagai: 1) unit kearsipan I, dan 2) unit/organ LKPT yang berada pada biro yang membidangi ketatausahaan. Kedua peraturan perundang-undangan tersebut menjelaskan kedudukan LKPT yang berbeda, yaitu menurut undang-undang, LKPT merupakan lembaga kearsipan di tingkat pusat, sementara menurut peraturan menteri, LKPT berfungsi sebagai unit pada biro yang menangani ketatausahaan.

Menyadari pentingnya penyelenggaraan kearsipan perguruan tinggi, berbagai perguruan tinggi di Indonesia mulai mendirikan LKPT. Universitas Gadjah Mada (UGM) menjadi universitas pertama yang mendirikan LKPT. LKPT di UGM diresmikan dengan nama Arsip Universitas Gadjah Mada (Arsip UGM) m e 1 a 1 u i $\quad$ K $\quad$ e k t o r
No.249/P/SK/HT/2004. Jika dilihat dari struktur organisasinya, arsip UGM bertanggung jawab langsung kepada rektor.

Lebih lanjut pada tahun 2009, Universitas Negeri Yogyakarta (UNY) yang menggunakan pola pengelolaan perguruan tinggi negeri badan layanan umum, bermaksud mendirikan LKPT. Namun pengusulan tersebut mendapat penolakan dari pemerintah karena alasan untuk mengurangi jumlah pejabat eselon II. Kearsipan UNY dimasukkan ke dalam fungsi ketatausahaan melalui terbitnya Peraturan Menteri Pendidikan Nasional Republik Indonesia nomor 23 tahun 2011 tentang Organisasi dan Tata Kerja Universitas Negeri Yogyakarta. Dalam peraturan tersebut disebutkan Subbagian Tata Usaha dan Kearsipan merupakan bagian dari Bagian Umum, Hukum, Tata Laksana, dan Perlengkapan.

Universitas Pembanguan Nasional Veteran Yogyakarta (UPN Veteran Yogyakarta), yang menjadi perguruan tinggi negeri setelah sebelumnya berstatus sebagai perguruan tinggi swasta, melakukan pengelolaan perguruan tinggi negeri dengan pola perguruan tinggi satuan kerja. Saat ini, UPN Veteran Yogyakarta dalam penyelenggaraan kearsipannya dilakukan oleh Sub Bagian Tata Usaha dan Rumah Tangga. Hal tersebut tercantum pada Peraturan Menteri Riset, Teknologi, dan Pendidikan Tinggi nomor 39 tahun 2015 tentang Organisasi dan Tata Kerja UPN VY 
Tabel 1. Perbandingan Status Pengelolaan PTN dan Kedudukan Lembaga Kearsipan di UGM, UNY, dan UPN Veteran Yogyakarta

\begin{tabular}{cccc}
\hline \hline Universitas & UGM & UNY & UPN VY \\
Status & PTN-BH & PTN-BLU & PTN-Satker \\
$\begin{array}{c}\text { Penyelenggara } \\
\text { Kearsipan }\end{array}$ & Arsip Universitas & Subbagian & $\begin{array}{c}\text { Fungsi Subbagian } \\
\text { Tata Usaha dan } \\
\text { Universitas }\end{array}$ \\
\hline \hline
\end{tabular}

Sumber: Peraturan Rektor Universitas Gadjah Mada Nomor1/P/Sk/Ht/2015

tentang Kedudukan, Fungsi, dan Tugas Organisasi di Lingkungan Universitas Gadjah Mada;

Peraturan Menteri Pendidikan Nasional Republik Indonesia Nomor 23 Tahun 2011 tentang Organisasi dan Tata Kerja Universitas Negeri Yogyakarta; dan

Peraturan Menteri Riset, Teknologi, dan Pendidikan Tinggi Nomor 39 Tahun 2015 tentang Organisasi dan Tata Kerja UPN Veteran Yogyakarta

Kedudukan LKPT sebagai penyelenggara kearsipan yang meliputi records management dan archives administration perlu untuk diatur lebih lanjut. Hal ini disebabkan oleh adanya wacana bahwa kearsipan di perguruan tinggi tidak perlu dilembagakan. Deliarnoor dan Aryawardana (2016:90) mengatakan bahwa menurut Kepala Biro Hukum dan Organisasi Kementerian Riset, Teknologi, dan Pendidikan Tinggi pada Workshop Revitalisasi Manajemen Arsip dan Dokumentasi sebagai Informasi Publik melalui Pengembangan Jaringan Informasi Perguruan Tinggi Negeri dan Kopertis di Surabaya pada 21-23 Oktober 2015, kedudukan LKPT adalah:

1. Merupakan fungsi pada unit kerja yang menangani ketatausahaan;

2. Sebagai salah satu unit kerja setingkat eselon IV pada Biro/Bagian; atau

3. Sebagai Unit Pelaksana Teknis (UPT) yang berada di bawah dan bertanggung jawab kepada pimpinan PTN.

Lebih lanjut dalam workshop tersebut terungkap bahwa Universitas Brawijaya, Universitas Pattimura, Universitas Bengkulu, dan Universitas Jember gagal memasukkan LKPT dalam Struktur Organisasi dan Tata Kerja (SOTK) masing-masing karena tidak dikabulkan oleh Kementerian Pendayagunaan Aparatur Negara dan Reformasi Birokrasi (Kementerian PANRB).

Dalam Workshop Revitalisasi Lembaga Kearsipan PTN di Bandung pada 21 April 2017, Deputi Bidang Tata Laksana Kementerian PANRB menyatakan bahwa:

1. Perguruan tinggi dapat membentuk arsip perguruan tinggi sebagai lembaga kearsipan perguruan tinggi 
yang juga berperan sebagai unit kearsipan tingkat I pada perguruan tinggi; dan

2. Sesuai dengan karakteristik tugas dan fungsinya, arsip perguruan tinggi berada pada unsur pelaksana administrasi non akademik pada perguruan tinggi.

Pernyataan tersebut disimpulkan dari pembahasan terhadap: (1) Peraturan Pemerintah nomor 28 tahun 2012 tentang Pelaksanaan Undang-Undang nomor 43 tahun 2009 tentang Kearsipan, dan (2) Peraturan Pemerintah nomor 4 tahun 2014 tentang Penyelenggaraan Pendidikan Tinggi dan Pengelolaan Perguruan Tinggi. Selain itu, juga dinyatakan bahwa kearsipan merupakan fungsi ketatausahaan dan kerumahtanggaan.

Dalam acara yang sama, Sekretaris Jenderal Kementerian Riset, Teknologi, dan Pendidikan Tinggi (Ristekdikti) menyatakan bahwa perkembangan kebijakan lembaga kearsipan PTN:

1. Hingga tahun 2012, LKPT merupakan fungsi unit kerja yang menangani ketatausahaan pada biro, atau sebagai unit kerja setingkat eselon IV pada biro;

2. Tahun 2012-2015, LKPT sebagai unit pelaksana teknis (UPT) yang berada dan bertanggungawab kepada pimpinan $\mathrm{PTN}$; dan

3. Tahun 2015 hingga sekarang, kembali sebagai fungsi unit kerja yang menangani ketatausahaan pada biro, atau sebagai unit kerja setingkat eselon IV pada biro.

Pernyataan tersebut merupakan hasil dari pembahasan Peraturan Menteri Ristekdikti nomor 15 tahun 2015 tentang Organisasi dan Tata Kerja Kementerian Riset, Teknologi, dan Pendidikan Tinggi. Dalam peraturan ini disebutkan bahwa salah satu fungsi Biro Keuangan dan Umum adalah pelaksanaan urusan kearsipan, keprotokolan, dan ketatausahaan.

Jika diamati secara seksama, pernyataan-pernyataan tersebut tidak sejalan dengan konsep fungsi unit kearsipan dan lembaga kearsipan yang tertuang pada Undang-Undang nomor 43 tahun 2009 tentang Kearsipan maupun Peraturan Pemerintah nomor 28 tahun 2012 tentang Pelaksanaan UndangUndang nomor 43 tahun 2009 tentang Kearsipan. Unit kearsipan merupakan satuan kerja pada pencipta arsip yang mempunyai tugas dan tanggung jawab dalam penyelenggaraan kearsipan. Peraturan Pemerintah nomor 28 tahun 2012 tentang Pelaksanaan UndangUndang nomor 43 tahun 2009 tentang Kearsipan menyebutkan bahwa unit kearsipan terdiri atas beberapa jenjang. Unit Kearsipan II berada pada satuan kerja di lingkungan sekretariat rektorat, fakultas, sivitas akademika, dan satuan kerja dengan sebutan lain. Sedangkan unit kearsipan I dilaksanakan oleh LKPT. Sementara itu, selain sebagai unit kearsipan I, LKPT memiliki fungsi, tugas, 
dan tanggung jawab di bidang pengelolaan arsip statis dan pembinaan kearsipan. Apabila dilihat dari konsep tersebut, seharusnya unit kerja yang menangani ketatausahaan merupakan unit kearsipan karena merupakan salah satu unit pencipta arsip, sementara LKPT merupakan lembaga kearsipan yang memiliki fungsi yang jauh berbeda.

Dari uraian tersebut, terdapat perbedaan yang cukup jelas mengenai kedudukan dan tugas LKPT dari beberapa peraturan perundang-undangan tersebut. Oleh karena itu, studi komparasi mengenai peraturan perundang-undangan tentang kearsipan menjadi penting dalam penyelenggaraan kearsipan di berbagai universitas di Indonesia.

\section{Rumusan Masalah}

Penelitian ini dilakukan terhadap tiga lembaga, yaitu: Arsip UGM sebagai LKPT di UGM, Sub Bagian Tata Usaha dan Kearsipan UNY sebagai penyelenggara ketatausahaan dan kearsipan di UNY, dan Sub Bagian Tata Usaha dan Rumah Tangga UPN VY sebagai pemegang fungsi kearsipan di UPN VY. Penelitian difokuskan pada penyelenggaraan kearsipan meliputi kegiatan records management yang terdiri atas kegiatan penciptaan, penggunaan dan pemeliharaan, dan penyusutan arsip; dan kegiatan archives administration yang meliputi kegiatan akuisisi, pengolahan, preservasi, dan akses arsip statis. Adapun kurun waktu yang diteliti adalah tahun
2016, 2017, dan 2018.

\section{Tujuan Penelitian}

Penelitian ini didesain untuk mengkaji kedudukan LKPT di Universitas Gadjah Mada (UGM), Universitas Negeri Yogyakarta (UNY), dan Universitas Pembangunan Nasional Veteran Yogyakarta (UPN Veteran Yogyakarta) dalam hubungannya dengan penyelenggaraan records management dan archives administration di univeritas masing-masing. Tujuan lain penelitian ini adalah untuk menganalisis pengaruh kedudukan penyelenggara kearsipan terhadap penyelenggaraan kearsipan pada ketiga institusi tersebut.

\section{Metodologi Penelitian}

Penelitian ini dilakukan dengan pendekatan kualitatif dengan model studi komparasi. Penelitian kualitatif menurut Pendit (2003:264) adalah suatu penelitian dengan memberikan perhatian yang seksama dan terinci terhadap hal yang berhubungan dengan suatu fenomena dan memperlakukan fenomena itu secara alamiah sesuai kenyataan yang ada.

Penelitian komparasi merupakan penelitian yang dilakukan untuk membandingkan suatu variabel (objek penelitian), antara subjek yang berbeda atau waktu yang berbeda dan menemukan hubungan sebab-akibatnya. Menurut Nazir (2017: 46) penelitian komparasi adalah sejenis penelitian deskriptif yang ingin mencari jawaban secara mendasar 
tentang sebab-akibat, dengan menganalisis faktor-faktor penyebab terjadinya ataupun munculnya suatu fenomena tertentu. Jadi penelitian komparatif adalah jenis penelitian yang digunakan untuk membandingkan antara dua kelompok atau lebih dari suatu variabel tertentu.

\section{Kerangka Pemikiran}

Kegiatan penyelenggaraan kearsipan di UGM, UNY, dan UPN Veteran Yogyakarta merupakan kegiatan yang dilakukan dalam rangka penyelamatan informasi yang terkandung dalam arsip sebagai bukti kegiatan pendidikan dan pengajaran, penelitian, serta pengabdian pada masyarakat di universitas masing-masing.

Penyelenggaraan kearsipan yang meliputi records management dan archives administration sesuai dengan amanat Undang-Undang Nomor 43 tahun 2009 tentang Kearsipan yaitu pengelolaan arsip dinamis dan pengelolaan arsip statis. Kedua fase tersebut terdiri atas kegiatannya masing-masing. Apabila divisualisasikan dalam bentuk gambar, model berpikir di atas adalah sebagai berikut:

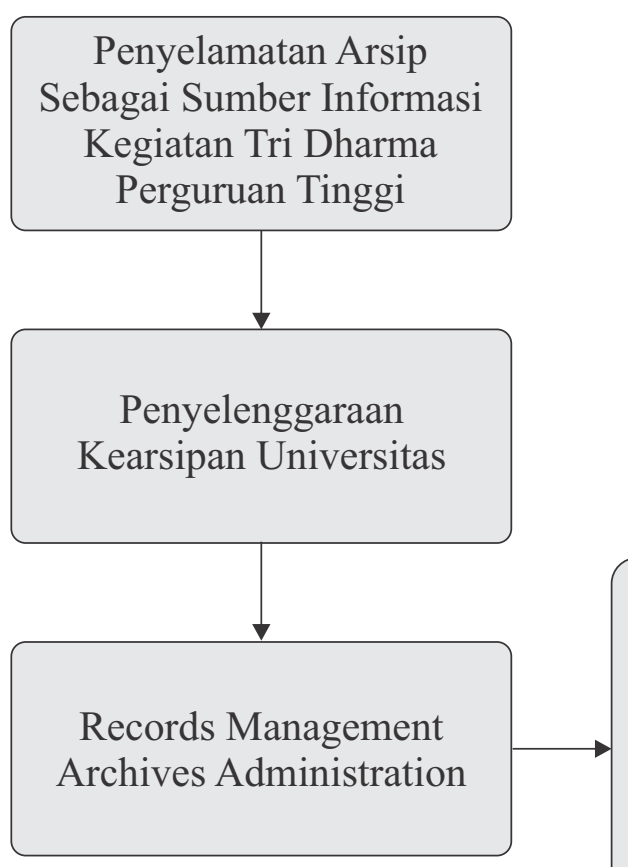

1. Penciptaan Arsip

2. Penggunaan dan pemeliharaan Arsip

3. Penyusutan Arsip

4. Akuisisi Arsip

5. Pengolahan Arsip

6. Preservasi Arsip

7. Akses Arsip

Gambar 1. Kerangka Pemikiran

Sumber: Analisis Peneliti 


\section{PEMBAHASAN}

\section{Praktik Records Management}

Pearce-Moses (2005:334) menyatakan bahwa records management adalah pengendalian arsip secara sistematis dan administratif sepanjang siklus hidup mereka untuk memastikan efisiensi dan penghematan dalam penciptaan, penggunaan, penanganan, pengendalian, pemeliharaan, dan disposisi. Griffin (2009:34) menyatakan bahwa records management merupakan bidang manajemen yang bertanggung jawab mengontrol secara efisien dan sistematis dalam pembuatan, penerimaan, pemeliharaan, penggunaan dan penyusutan arsip.

Records management dalam perspektif Undang-Undang nomor 43 tahun 2009 tentang Kearsipann dimaknai dengan istilah pengelolaan arsip dinamis, yaitu proses pengendalian arsip dinamis secara efisien, efektif, dan sistematis meliputi kegiatan penciptaan, penggunaan dan pemeliharaan, serta penyusutan. Arsip tercipta melalui pembuatan dan penerimaan. Sementara itu, penggunaan dan pemeliharaan merupakan tahap utama arsip dinamis. Sedangkan penyusutan merupakan pengurangan jumlah arsip.

1. Penciptaan Arsip

Penciptaan arsip di UGM berasal dari pembuatan dan penerimaan arsip. Dalam tiga tahun terakhir, penciptaan arsip di Arsip UGM berasal dari pembuatan surat keluar dan penerimaan surat masuk. Sebagai satuan kerja universitas, surat masuk dan surat keluar tercipta melalui kegiatan administrasi di Arsip UGM. Sementara itu, surat masuk dan surat keluar yang ditujukan kepada universitas dikelola oleh Sub-Bagian Tata Usaha universitas. Dalam tiga tahun terakhir, Arsip UGM menerima surat masuk dan membuat surat keluar d a la m rangka kegiat a n administrasinya. Dalam buku agenda persuratan disebutkan bahwa pada tahun 2016, surat masuk sebanyak 681 surat, dan surat keluar sebanyak 382 surat. Pada 2017, surat masuk sebanyak 606 surat dan surat keluar sebanyak 453 surat. Sedangkan tahun 2018 surat masuk sebanyak 475 surat dan surat keluar sebanyak 322 surat.

Sementara itu, penciptaan arsip di UNY juga berasal dari persuratan. Berbeda dengan Arsip UGM, Sub-Bagian Tata Usaha\& Kearsipan UNY mengelola surat masuk dan surat keluar yang ditujukan kepada universitas. UNY telah menggunakan aplikasi pengurusan surat masuk yaitu $M y$ Office dan aplikasi pengurusan surat keluar yaitu Siagen. Dengan aplikasi tersebut, surat masuk kemudian dialihmediakan menjadi bentuk digital dan kemudian dikirimkan kepada pimpinan melalui sistem. Sebagai pelaksana tata usaha 
rektorat, Sub-Bagian Tata Usaha dan Kearsipan UNY menciptakan arsip lebih banyak daripada Arsip UGM sebagai satuan kerja universitas. Dalam aplikasi My Office disebutkan bahwa pada tahun 2016, surat masuk sebanyak 9573 surat dan surat keluar sebanyak 3693 surat. Sementara itu pada tahun 2017 surat masuk sebanyak 9987 surat dan surat keluar sebanyak 5176 surat. Sedangkan pada 2018 surat masuk sebanyak 10800 surat dan surat keluar sebanyak 6858 surat.

Penciptaan arsip di UPN Veteran Yogyakarta tidak jauh berbeda dari UGM dan UNY yaitu berasal dari kegiatan persuratan. Pengurusan surat untuk rektorat dilakukan oleh Sub-Bagian Tata Usaha dan Rumah Tangga UPN Veteran Yogyakarta. Pengurusan surat dilakukan secara manual dengan menggunakan buku agenda. Data pada buku agenda tersebut menunjukkan bahwa pada tahun 2016, surat masuk sebanyak 3666 surat dan surat keluar sebanyak 3400 surat. Data tahun 2017 surat masuk sebanyak 3075 surat dan surat keluar sebanyak 3167 surat. Sementara itu, pada tahun 2018 surat masuk sebanyak 3122 surat dan surat keluar sebanyak 8332 surat.

2. Penggunaan dan Pemeliharaan Arsip $\mathrm{P}$ e $\mathrm{ng} \mathrm{g} \mathrm{u}$ a a $\mathrm{n}$ a $\mathrm{n}$ pemeliharaan arsip merupakan tahap ke dua dari praktik records management. Arsip digunakan dan dipelihara selama jangka waktu tertentu sesuai dengan kebutuhan kegiatan administrasi. Dalam kegiatan penggunaan dan pemeliharaan arsip, dikenal istilah pemberkasan arsip, yaitu dikelompokkannya arsip yang tercipta secara sistematis berdasarkan subjek atau perihal informasi yang terkandung dalam arsip.

Dalam upaya menggunakan dan memelihara arsip, Arsip UGM melakukan pemberkasan terhadap seluruh arsip yang tercipta. Sarana penggunaan dan pemeliharaan arsip yang digunakan adalah filing cabinet. Jumlah arsip yang diberkaskan selama tahun 2016-2018 adalah sama dengan jumlah penciptaan arsip pada tahun yang sama.

Sementara itu, pemberkasan arsip di Sub-Bagian Tata Usaha dan Kearsipan UNY dan Sub-Bagian Tata Usaha dan Rumahh Tangga UPN Veteran Yogyakarta juga telah dilakukan untuk semua arsip yang tercipta pada tahun 2016-2018. Adapun sarana pemberkasan yang digunakan adalah filing cabinet .

3. Penyusutan Arsip Dinamis

Undang-Undang nomor 43 tahun 2009 tentang Kearsipan menyebutkan bahwa penyusutan arsip adalah kegiatan pengurangan jumlah arsip dengan cara: (1) 
pemindahan arsip inaktif dari unit pengolah ke unit kearsipan, (2) pemusnahan arsip yang tidak memiliki nilai guna, dan (3) penyerahan arsip statis kepada lembaga kearsipan.

Selama tahun 2016-2018, Arsip UGM telah melakukan penyusutan arsip berupa pemindahan arsip inaktif dari central file ke records center. Kegiatan pemusnahan dan penyerahan arsip di Arsip UGM tidak dilakukan selama tahun 2016-2018. Pemindahan arsip yang dilakukan dalam tiga tahun terakhir dilakukan terhadap arsip yang tercipta pada tahun 2016. Dalam daftar arsip inaktif disebutkan bahwa selama tiga tahun terakhir, jumlah arsip yang disusutkan adalah 1063 berkas.

Sementara itu, kegiatan penyusutan di UNY juga baru dilakukan dengan model pemindahan arsip. Kegiatan pemusnahan dan penyerahan arsip di Sub-Bagian Tata Usaha dan Kearsipan UNY tidak dilakukan selama tahun 2016-2018. Proses pemindahan arsip inaktif di UNY dilakukan terhadap arsip yang tercipta pada tahun 2016 dengan cara memindah arsip dari filing cabinet ke dalam boks dan memindahkannya ke ruang records center. Dalam daftar arsip inaktif disebutkan bahwa dalam tiga tahun terakhir, jumlah arsip yang disusutkan adalah 13266 berkas.

Penyusutan arsip di SubBagian Tata Usaha dan Rumah Tangga UPN Veteran Yogyakarta dilakukan dengan proses pemindahan. Sementara itu kegiatan pemusnahan dan penyerahan arsip di Sub-Bagian Tata Usaha dan Rumah Tangga UPN Veteran Yogyakarta tidak dilakukan selama tahun 20162018. Pemindahan arsip inaktif di Sub-Bagian Tata Usaha dan Rumah Tangga UPN Veteran Yogyakarta dilakukan dengan memindah arsip dari almari arsip aktif ke almari arsip inaktif. Adapun jumlah arsip yang disusutkan sebagaimana dalam daftar arsip disusutkan adalah 13308 berkas.

Berikut adalah komparasi kegiatan records management di Arsip UGM, Sub-Bagian Tata Usaha dan Kearsipan UNY, dan Sub-Bagian Tata Usaha dan Rumah Tangga UPN Veteran Yogyakarta selama tahun 2016-2018: 


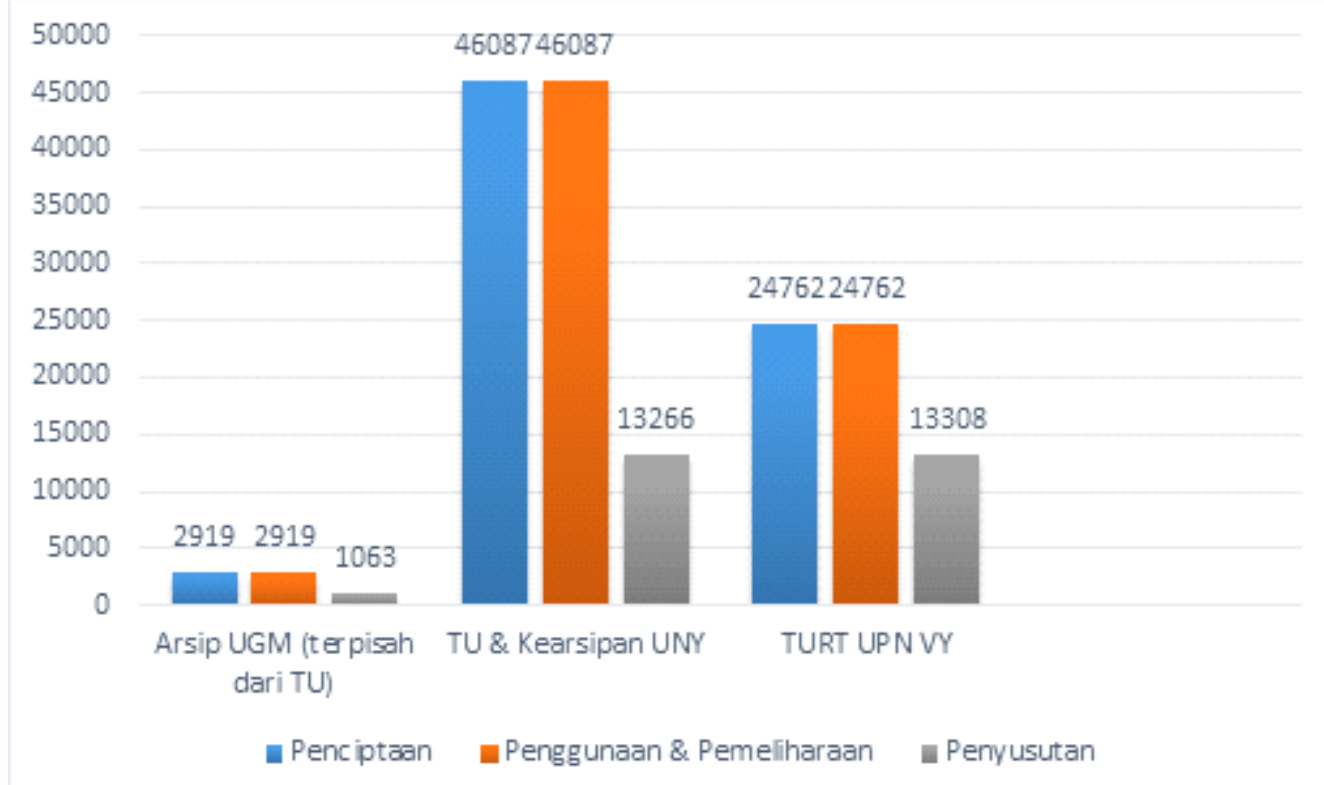

Gambar 2. Komparasi Records Management

di Arsip UGM (terpisah dari TU), Sub Bagian Tata Usaha \& Kearsipan UNY, dan Sub Bagian Tata Usaha dan Rumah Tangga UPN Veteran Yogyakarta tahun 2016-2018

Sumber: Hasil Observasi

\section{Praktik Archives Administration}

Arsip statis dikelola oleh lembaga kearsipan dengan konsep archives administration. Archives administration (pengelolaan arsip statis) menurut Scwirtlich (1993:28) adalah akuisisi, penataan dan deskripsi, preservasi, akses, dan edukasi kepada komunitas. Sementara itu, Pearce-Moses (2005:33) menyatakan bahwa archives management, yang disebut juga sebagai archival administration, adalah pengawasan umum program untuk menilai, memperoleh, mengatur dan mendeskripsikan, melestarikan, mengotentikasi, dan menyediakan akses arsip yang bernilai permanen. UndangUndang nomor 43 tahun 2009 tentang
Kearsipan menyebutkan bahwa pengelolaan arsip statis meliputi: akuisisi, pengolahan, preservasi, dan akses.

1. Akuisisi Arsip

Akuisisi merupakan proses penambahan khasanah arsip statis pada lembaga kearsipan yang dilaksanakan melalui kegiatan penyerahan arsip statis dan hak pengelolaannya dari pencipta arsip kepada lembaga kearsipan. Dalam daftar akuisisi masing-masing lembaga/institusi disebutkan bahwa akuisisi yang dilakukan oleh Arsip UGM selama tahun 2016-2018 berasal dari unit kerja di lingkungan UGM dan juga dari perseorangan sejumlah 1940 berkas. Sementara itu akuisisi di Sub-Bagian 
Tata Usaha dan Kearsipan UNY diperoleh dari Unit Layanan Pengadaan (ULP), Bagian Hukum dan Tata Laksana, dan dari Kantor Kerja Sama. Proses akuisisi di Sub-Bagian Tata Usaha dan Kearsipan UNY dilakukan secara sederhana, yaitu atas dasar perintah pimpinan secara lisan. Adapun jenis arsip yang diakuisisi oleh Sub-Bagian Tata Usaha dan Kearsipan UNY adalah arsip tekstual dan gambar teknik sebanyak 2725 berkas.

Akuisisi arsip di Sub-Bagian Tata Usaha dan Rumah Tangga UPN Veteran Yogyakarta selama tahun 2016-2018 dilakukan terhadap arsip Wakil Rektor I dan II, dan juga dari beberapa unit kerja. Prosedur akuisisi arsip di Sub-Bagian Tata Usaha dan Rumah Tangga UPN Veteran Yogyakarta dilakukan berdasarkan perintah secara lisan. Adapun jenis arsip yang diakuisisi adalah arsip tekstual dan gambar bangunan sebanayak 100 berkas sebagaimana disebutkan dalam daftar akuisisi arsip statis.

2. Pengolahan Arsip

Pengolahan arsip statis merupakan tahap ke dua dalam kegiatan archives administration setelah akuisisi. Tujuan pengolahan arsip adalah agar arsip teratata dan mudah untuk ditemukan kembali. Pengolahan arsip juga bertujuan agar arsip dapat diolah menjadi informasi.

Pengolahan arsip di Arsip
UGM didasarkan pada standar pengolahan arsip statis. Pengolahan arsip statis di Arsip UGM tidak terlepas dari kegiatan akuisisi, yaitu dimulai dengan penilaian arsip, kemudian arsip yang dinilai sebagai arsip statis tersebut dibuatkan daftar arsip statis. Dalam daftar pengolahan arsip disebutkan bahwa selama tahun 20162018, Arsip UGM telah mengolah arsip statis hasil akuisisi sebanyak 1870 berkas. Pengolahan arsip statis di Arsip UGM diawali dengan pembuatan skema arsip statis dan hasil akhirnya berupa daftar arsip statis. Berikut adalah arsip yang masuk dalam kategori arsip statis di Arsip UGM:

a. Surat Keputusan (SK), meliputi SK Majelis Wali Amanat (MWA), SK Senat Akademik (SA), risalah rapat SA, SK Majelis Guru Besar (MGB), notula rapat MGB, SK Rektor;

b. Laporan, meliputi laporan SA, laporan MGB, laporan tahunan Rektor, laporan tahunan keuangan;

c. Kerja sama, meliputi kerja sama dalam negeri dan luar negeri;

d. Personal file, meliputi personal file pejabat struktural;

e. Arsip akademik, meliputi: data heregistrasi mahasiswa, berkas kurikulum, berkas Kuliah Kerja Nyata, dan Bahan Ajar;

f. Personal paper meliputi: pidato pengukuhan Guru Besar, laporan 
penelitian, pidato Presiden di UGM, disertasi, pidato Honoris Causa, pidato ilmiah Dies Natalis, pidato ilmiah stadium generale, pidato penghargaan HB IX Awards, makalah seminar, personal papers;

g. Arsip publikasi, meliputi: kliping media masa, terbitan fakultas dan unit kerja, terbitan-terbitan berkala

h. Koleksi spesial, meliputi: otonomi perguruan tinggi, UGM Cabang Magelang, Yayasan Iso, Yayasan Hatta, sertifikasi rangking dan usulan UGM, peraturan perundang-undangan terkait UGM; SK Menteri tentang Rektor atau MWA

i. Koleksi referensi, meliputi: Buku Panduan Akademik, profil UGM dan unit kerja, Buku Petunjuk Masuk UGM, statistik lulusan, asal sekolah mahasiswa, statistik mahasiswa;

j. Arsip anniversary, meliputi: Dies Natalis dan Sejarah UGM, Buku Wisuda;

k. Arsip society, meliputi: berkas alumni dan mahasiswa;

1. Arsip institusi dan properti, meliputi: tanah dan gedung, lembaga dan badan usaha

Sementara itu, pengolahan arsip statis di UNY tidak jauh berbeda dengan teori pengolahan arsip, seperti deskripsi dan manuver arsip. Selama tahun 2016-2018, Sub-Bagian Tata Usaha dan Kearsipan UNY telah mengolah sebagian arsip hasil akuisisi yaitu sebanyak 1138 berkas sebagaimana disebutkan dalam daftar pengolahan arsip, bahwa arsip yang masuk dalam kategori arsip statis di UNY yaitu:

a. Perencanaan, meliputi: Master Plan Bidang Pendidikan, Rencana Pembangunan Jangka Menengah, Program Kerja Tahunan, Penetapan Rektor, Laporan Tahunan, LAKIP, Laporan Insidental, Laporan Monitoring dan Evaluasi, Evaluasi Program UNY, Evaluasi Program Mahasiswa;

b. Produk Hukum, meliputi: Peraturan Rektor, SK Rektor, Peraturan Dekan/Direktur/Ketua $\mathrm{L}$ e $\mathrm{m} \mathrm{b}$ a $\mathrm{g}$ a, $\quad \mathrm{S} \mathrm{K}$ Dekan/Direktur/Ketua Lembaga, Instruksi Rektor;

c. Kerja Sama, meliputi: Kerja Sama Dalam Negeri dan Luar Negeri;

d. Instrumen Hukum, meliputi: Standar/Pedoman, Prosedur Kerja, Surat Edaran,;

e. Kasus/Sengketa Hukum, meliputi: Pidana, Perdata, Tata Usaha Negara, Arbitrase, SengketaAdat

f. Hak Kekayaan Intelektual;

g. Organisasi dan Tata Laksana, meliputi: SOTK, Statuta, Analsis Jabatan; 
h. Perlengkapan, meliputi: Penghapusan Barang;

i. Ketatausahaan, meliputi: rapat pimpinan, pemusnahan arsip, penyerahan arsip, berkas alih media arsip;

j. Kehumasan, meliputi: kunjungan dinas rektor, master penerbitan media masa cetak dan elektronik, penghargaan;

k. Pendidikan dan Pelatihan, meliputi: pedoman kediklatan, akreditasi lenbaga diklat, sertifikasi sumber daya manusia kediklatan, STTPL peserta diklat;

1. Informatika, meliputi: master plan sistem informasi;

m. Pengawasan, meliputi: laporan audit;

n. APBN, meliputi: ketentuan peraturan perundang-undangan, pengelolaan barang milik negara, laporan keuangan tahunan, bantuan luar negeri, laporan hutang negara; dan

o. Kepegawaian, meliputi: penetapan formasi khusus, SK CPNS/PNS kolektif;.

Pengolahan arsip statis di UPN Veteran Yogyakarta masih dilakukan dalam tahap penataan. Deskripsi terhadap arsip statis dilakukan dengan membuat daftar arsip berupa agenda. Adapun jumlah arsip yang diolah adalah sebanyak 100 berkas. Arsip yang termasuk dalam kategori statis di UPN Veteran
Yogyakarta yaitu:

a. Surat Keputusan Rektor, Dekan, dan Ketua Lembaga;

b. Peraturan Rektor, Dekan, dan Ketua Lembaga;

c. Surat-surat dari kementerian;

d. Gambar gedung;

e. Nota dinas, dan

f. Surat perintah.

3. Preservasi Arsip

$\mathrm{T}$ a h a $\mathrm{p}$ archives administration setelah pengolahan arsip adalah preservasi arsip statis. Preservasi arsip statis dilakukan untuk menjamin keselamatan dan kelestarian arsip statis dengan cara mencegah kerusakan (preservasi preventif) dan perbaikan (preservasi kuratif). Preservasi preventif yang dilakukan di Arsip UGM meliputi penyediaan ruang simpan arsip (depo). Depo arsip statis di Arsip UGM dilengkapi dengan pengatur suhu udara ( $a$ ir conditioner/AC), alat pengatur kelembaban berupa dehumidifier, dan alat pemadam kebakaran. Ruang depo arsip statis terhindar dari cahaya matahari secara langsung. Dalam rangka pengendalian hama, Arsip UGM melakukan kegiatan fumigasi, pemberian kamper, dan silica gel. Selain itu, Arsip UGM melakukan alih media arsip statis sebagai salah satu upaya preservasi preventif.

Sementara itu, preservasi preventif di UNY dilakukan terhadap 
ruang penyimpanan arsip yang dilengkapi dengan pendingin udara, pemberian kamper, dan pemberian silica gel. Pembersihan ruang secara berkala dilakukan dalam rangka pengendalian hama terpadu.

Preservasi arsip statis di Sub-Bagian Tata Usaha dan Rumah Tangga UPN Veteran Yogyakarta dilakukan dengan penyedian ruang simpan arsip. Seperti di UGM dan UNY, ruang penyimpanan arsip di UPN Veteran Yogyakarta juga menggunakan pendingin udara.

Selain preservasi yang bersifat preventif, Arsip UGM juga melakukan preservasi kuratif berupa kegiatan laminasi dan enkapsulasi. Arsip UGM melakukan preservasi kuratif Arsip UGM melalui metode laminasi dan enkapsulasi. Dalam tiga tahun terakhir jumlah arsip yang dilaminasi adalah 8189 berkas. Sementara itu Sub-Bagian Tata Usaha dan Kearsipan UNY dan Sub-Bagian Tata Usaha dan Rumah Tangga UPN Veteran Yogyakarta belum melakukan kegiatan preservasi kuratif karena keterbatasan sumber daya manusia, peralatan, dan anggaran.

4. Akses Arsip

Akses arsip merupakan tahap akhir archives administration. Akses merupakan pemanfaatan dari semua upaya pengarsipan. Arsip akan berdaya guna apabila diakses oleh masyarakat dalam berbagai kepentingan. Greene (2009:33-34) menyatakan bahwa tugas dari seorang arsiparis tidak hanya mengumpulkan dan melestarikan materi dokumenter, tetapi juga harus membuatnya dapat diakses oleh orang lain. Sementara itu, Rhee (2015:37) menyatakan bahwa lembaga kearsipan memiliki tugas layanan bagi pengguna. Lembaga kearsipan membatasi layanan kepada pengguna karena dua alasan, yaitu: prioritas pelestarian arsip tradisional dan sumber daya kelembagaan yang terbatas, terutama dalam hal waktu layanan. Namun, perkembangan teknologi dapat membantu lembaga kearsipan dalam penyediaan akses arsip. Scwirtlich (1993:28) menyebutkan bahwa akses arsip berkenaan dengan kebijakan layanan untuk pengguna arsip mengingat sifat arsip yang unik dan tidak tergantikan.

Dalam daftar layanan arsip masing-masing institusi desebutkan bahwa selama tahun 2016-2018, volume akses arsip statis di Arsip UGM cukup tinggi, yaitu sebanyak 2677 berkas. Sementara itu akses arsip statis di UNY sebanyak 71 berkas. Sedangkan layanan akses di SubBagian Tata Usaha dan Rumah Tangga UPN Veteran Yogyakarta sebanyak 140 berkas.

Berikut adalah komparasi kegiatan archives administration di Arsip UGM, Sub-Bagian TUK UNY, dan Sub-Bagian TURT UPN VY: 


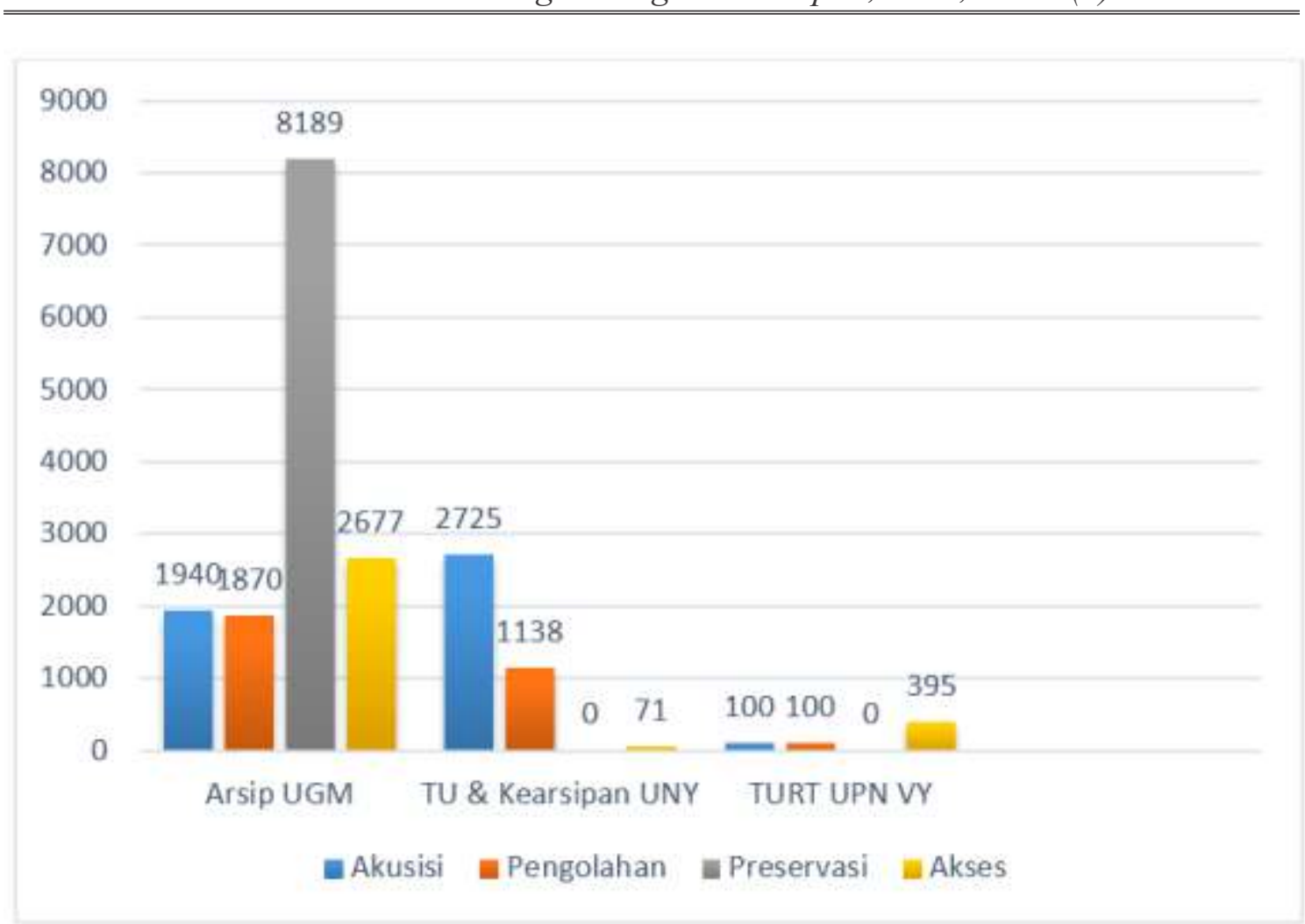

Gambar 3. Komparasi Archives Administration

di Arsip UGM, Sub Bagian Tata Usaha \& Kearsipan UNY, dan Sub Bagian Tata Usaha dan Rumah Tangga UPN Veteran Yogyakarta tahun 2016-2018

Sumber: Hasil Observasi

Pengaruh Kedudukan Lembaga

Kearsipan dalam Praktik Kearsipan

\section{Perguruan Tinggi}

Penyelenggara kearsipan di UGM adalah Arsip Universitas Gadjah Mada yang berkedudukan sebagai lembaga kearsipan di sekretariat universitas. Kedudukan arsip universitas ini tertuang dalam Peraturan Rektor UGM Nomor 1/P/SK/HT/2015 tentang Kedudukan, Fungsi, dan Tugas Organisasi di Lingkungan Universitas Gadjah Mada. Arsip UGM dipimpin oleh seorang kepala yang membawahi dua kepala bidang, yaitu: 1) Kepala Bidang Inovasi, Pelestarian, dan Konservasi Arsip; dan 2) Kepala Bidang Informasi dan
Pengembangan Sistem Kearsipan. Kepala Arsip UGM dan masing-masing kepala bidang memiliki rincian tugas masingmasing serta membawahi kelompok arsiparis dan pengelola arsip. Kedudukan Arsip Universitas dalam struktur organisasi di UGM sangat berpengaruh pada penyelenggaraan kearsipan di UGM.

Sementara itu penyelenggara kearsipan di UNY adalah Sub-Bagian Tata Usaha dan Kearsipan. Hal ini tertuang dalam Peraturan Menteri Pendidikan Nasional Republik Indonesia Nomor 23 Tahun 2011 tentang Organisasi dan Tata Kerja Universitas Negeri Yogyakarta. Sub-Bagian Tata Usaha dan Kearsipan berada di bawah Bagian Umum, Hukum, 
Tata Laksana dan Perlengkapan (UHTP). Bagian UHTP berada di bawah Biro Umum, Perencanaan, dan Keuangan (BUPK).

Kedudukan penyelenggara kearsipan di UNY yang berada di tingkat sub- bagian berpengaruh pada kegiatan kearsipan. Kedudukan itu menurut Kepala Sub-Bagian Tata Usaha dan Kearsipan UNY kurang ideal. Dalam merespon permasalahan tersebut, pada tahun 2009 UNY telah mengajukan usulan ke pemerintah untuk mendirikan UPT kearsipan, namun usulan tersebut ditolak. Penyelenggaraan kearsipan UNY telah menjangkau fakultas-fakultas di lingkungan UNY. Kegiatan kearsipan yang melibatkan fakultas di antaranya adalah pelatihan, sosialisasi, dan akuisisi. Namun kegiatan ini mengalami kendala, yaitu petugas kearsipan di fakultas belum memiliki pemahaman yang cukup tentang kearsipan.

Penyelenggara kearsipan di UPN Veteran Yogyakarta tidak berkedudukan sebagai unit atau lembaga, namun sebagai fungsi ketatausahaan. Dalam Peraturan Menteri Riset, Teknologi, dan Pendidikan Tinggi Republik Indonesia Nomor 39 Tahun 2015 Tentang Organisasi dan Tata Kerja Universitas Pembangunan Nasional "Veteran" Yogyakarta, disebutkan bahwa kearsipan adalah salah satu tugas SubBagian Tata Usaha dan Rumah Tangga ( T URT). Sub-Bagi an TURT berkedudukan di bawah Bagian Umum,
Hukum, Tata Laksana, dan Barang Milik Negara. Bagian tersebut berkedudukan di bawah Biro Umum dan Keuangan. Senada dengan yang terjadi di UNY, penyelenggaraan kearsipan UPN Veteran Yogyakarta mengalami beberapa kendala, diantaranya adalah kedudukan penyelenggara kearsipan di tingkat sub bagian dan kurangnya sumber daya manusia. Sub-Bagian TURT didukung oleh sembilan staf, namun hanya satu staf yang ditugaskan mengelola arsip. Penyelenggaraan kearsipan di UPN Veteran Yogyakarta belum menjangkau fakultas di lingkungan UPN Veteran Yogyakarta, terutama dalam kegiatan akuisisi. Hingga saat ini belum pernah dillakukan koordinasi di bidang kearsipan dalam lingkup universitas dan fakultas.

Perbedaan kedudukan penyelenggara kearsipan perguruan tinggi pada struktur organisasi universitas berpengaruh pada rincian tugas organisasi. Arsip UGM yang berada pada sekretariat universitas bertanggung jawab kepada rektor. Arsip UGM juga memiliki struktur organisasi yang kompleks, sehingga rincian tugasnya pun lebih banyak daripada UNY dan UPN Veteran Yogyakarta. Sementara kedudukan penyelenggara kearsipan di UNY dan UPN Veteran Yogyakarta berada pada level lebih rendah, dan dipimpin oleh pejabat Eselon IV, sehingga rincian tugasnya pun lebih sederhana. 


\section{KESIMPULAN}

Dalam menyelenggarakan records management, Arsip UGM, Sub-Bagian Tata Usaha dan Kearsipan UNY, dan SubBagian TURT UPN Veteran Yogyakarta telah melaksanakan kegiatan: a) penciptaan, b) penggunaan dan pemeliharaan, dan c) penyusutan arsip. Kegiatan penciptaan arsip di Arsip UGM relatif lebih rendah jika dibandingkan dengan Sub-Bagian Tata Usaha dan Kearsipan UNY dan Sub-Bagian TURT UPN Veteran Yogyakarta karena Arsip UGM terpisah dari Unit Tata Usaha di UGM. Penciptaan arsip di UGM lebih banyak dilakukan oleh Unit Tata Usaha Universitas.

S e mentara itu, dalam menyelenggarakan archives administration, Arsip UGM, Sub-Bagian Tata Usaha dan Kearsipan UNY, dan SubBagian TURT UPN Veteran Yogyakarta telah melaksanakan kegiatan a) akuisisi, b) pengolahan, c) preservasi, dan d) akses. Kegiatan archives administration di Arsip UGM relatif lebih tinggi jika dibandingkan dengan Sub-Bagian Tata Usaha dan Kearsipan UNY dan SubBagian TURT UPN Veteran Yogyakarta karena ketersediaan sumber daya manusia yang mendukung. Jumlah sumber daya manusia kearsipan di Sub-Bagian Tata Usaha dan Kearsipan UNY dan SubBagian TURT UPN Veteran perlu ditambah.

Terbitnya Permenristekdikti Nomor 78 tahun 2017 tentang
Penyelenggaraan Kearsipan di Lingkungan Kementerian Riset, Teknologi, dan Pendidikan Tinggi yang menempatkan kedudukan LKPT berbeda dengan yang diamanahkan oleh UndangUndang nomor 43 tahun 2009 dan Peraturan Pemerintah nomor 28 tahun 2012 menjadi wacana baru yang layak untuk diperbincangkan. Dalam Konferensi Nasional Lembaga Kearsipan Perguruan Tinggi Negeri di Jatinangor pada 21 April 2017 yang dihadiri oleh Kepala Arsip Nasional Republik Indonesia (ANRI), perwakilan Sekretariat Jenderal Kemenristekdikti, Deputi Bidang Kelembagaan dan Tata Laksana Kementerian Pendayaan Aparatur Negara dan Reformasi Birokrasi, serta anggota Perkumpulan Arsip Perguruan Tinggi Indonesia (PAPTI), disampaikan makalah-makalah dari masing-masing pihak yang hadir. Dalam pemaparan makalahnya, belum ditentukan titik temu dari perbedaan kedudukan LKPT. Hingga saat ini kedudukan LKPT dalam undangundang dengan peraturan pemerintahnya masih berbeda dengan Permenristekdikti tersebut. Dapat disimpulkan bahwa ANRI dan PAPTI mempunyai kecenderungan mengikuti amanah undang-undang. Adapun kecenderungan UGM, UNY, dan UPN VY masih menempatkan kedudukan LKPT sesuai dengan Struktur Organisasi dan Tata Kerja (SOTK) nya masingmasing.

Penulis menyarankan agar kelembagaan arsip perguruan tinggi 
sebaiknya ditetapkan secara jelas dan terpisah dari unit dan fungsi ketatausahaan. Dalam rangka praktik kearsipan perguruan tinggi, lembaga kearsipan perlu meningkatkan sumber daya manusia, sarana dan prasarana kearsipan, anggaran dan belanja, kebijakan berupa pedoman-pedoman kearsipan, sistem informasi kearsipan, dan sosialisasi kepada masyarakat agar penyelenggaraan kearsipan dapat dilaksanakan secara optimal.

\section{DAFTAR PUSTAKA}

Cohen, M.D and March, J.G., 1986, Leadership and Ambiguity: The American College President, 2nd. ed., Boston: Harvard Business School Press

Cook, Terry, 2013, "Evidence, memory, identity, and community: four shifting archival paradigms," Archival Science, 13, 95-120

Deputi Bidang Kelembagaan dan Tata Laksana Kementerian Pendayagunaan Aparatur Negara dan Reformasi Birokrasi, 2017, "LKPT dalam Struktur Perguruan Tinggi., Disampaikan pada Konferensi Nasional Penguatan dan Pemberdayaan Lembaga Kearsipan Perguruan Tinggi di Bandung, 21 April 2017.

Deliarnoor, N.A., \& Aryawardhana, T. 2016. Lembaga Kearsipan Perguruan Tinggi. Bandung: Unpad Press.

Greene, Mark A., The Power of Archives: Archivists' Values and Value in the Postmodern Age, The American Archivists, 72, 17-41

Griffin, Andrew, dkk. 2009. Glosary of Terms. London: International Records Management Trust

Kirchhoff, T., Schweibenz, W., dan Sieglerschmidt, J. 2008. "Archives, Libraries, Museums and the Spell of Ubiquitous Knowledge", Archival Science, $8,251-266$

Nazir, Moh., 2017, Metode Penelitian, Bogor: Ghalia Indonesia

Pearce-Moses, R., 2005, A Glosary of Archival and records Therminology, Chicago: Society of American Archivists

Pendit, P.L., 2003, Penelitian Ilmu Perpustkaan dan Informasi: Suatu Pengantar Diskusi Epistemologi dan Metodologi. Jakarta: JIP-FSUI.

Peraturan Menteri Riset, Teknologi, dan Pendidikan Tinggi nomor 15 tahun 2015 tentang Organisasi dan Tata Kerja Kementerian Riset, Teknologi, dan Pendidikan Tinggi.

Peraturan Menteri Riset, Teknologi, dan Pendidikan Tinggi nomor 78 $\mathrm{t}$ a h u n 2017 t e n t a n g Penyelenggaraan Kearsipan di Lingkungan Kementerian Riset, Teknologi, dan Pedidikan Tinggi

Peraturan Pemerintah nomor 28 tahun 2012 tentang Pelaksanaan Undang-undang nomor 43 tahun 2009 tentang Kearsipan

Peraturan Rektor UGM Nomor $1 / \mathrm{P} / \mathrm{SK} / \mathrm{HT} / 2015$ tentang Kedudukan, Fungsi, dan Tugas 
Organisasi di Lingkungan Universitas Gadjah Mada

Rhee, Hea Lim ., 2015, Reflections on Archival User Studies. American Library Association. 54(4), 2942

Ricks, M \& Gow, K. 1988. Information Resources Management. A Records System Approach. 2nd edition. Cincinnati: SouthWestern Publishing

Schwartz, J.M And Cook, Terry., 2002, Archives, Records, and Power: The Making of Modern Memory, Archival Science. 2. 1-19

Scwirtlich.A.M., 1993, Getting organized dalam J Ellis 9ed.) Keeping Archives (2 nd. Ed.25-73), Port Melbourne: DW Thorpe
Stern, Bayard, 2007, Mary Lou Norwood, d a 1 a m $F S U N e w s$ http://fsu.edu/news/2007/04/12/ norwood.doctorate/ diakses pada 30 September 2017

Sulistyo-Basuki,2005, Kamus Istilah Kearsipan, Yogyakarta: Kanisius

Undang-Undang Republik Indonesia Nomor 43 Tahun 2009 tentang Kearsipan 